\title{
Szkolnictwo polskie na Lotwie w okresie międzywojennym
}

Mniejszość polska na Lotwie w okresie międzywojennym była czwarta po Rosjanach, Żydach i Niemcach (po wyjeździe ostatnich do Niemiec w roku 1939 - trzecia). Polaków w roku 1930 było 59374, co stanowiło około 3\% ogółu mieszkańców państwa. Podczas innych spisów ludności liczby te się zmienialy, ale nieznacznie. Większa część Polaków Lotwy pochodziła z Latgalii (byłych Inflant Polskich), gdzie kultura polska, dzięki wpływowi ziemiaństwa polskiego, zachowala swoje znaczenie do XX wieku, nie zważając nawet na politykę rusyfikacji rządu rosyjskiego w XIX wieku.

Szkolnictwo polskie miało stosunkowo dawną historię na Lotwie. Zapoczątkowane jeszcze przez jezuitów w wieku XVI - XVII, w okresie rusyfikacji w drugiej połowie XIX wieku przetrwało w nieoficjalnych szkólkach prywatnych w majątkach ziemiańskich Latgalii, do których chętnie posyłali swoje dzieci również chłopi łotewscy, którzy nie mogli przyjąć narzucania im prawosławia w szkołach rządowych. U schyłku XIX wieku w Rydze pracę rozpoczęły trzy pensje dla polskich dziewcząt z których dwie później przekształcono w prywatne gimnazja. Wykładano w nich również język polski, historię i geografię Polski. Po 1906 roku zarejestrowane w Rydze polskie towarzystwo „Oświata” rozpoczęło pracę nad organizacją i otworzyło kilka polskich szkół podstawowych. Nauczanie języka polskiego rozpoczęto również w szkole parafialnej w Rzeżycy (Rēzekne) ${ }^{\perp}$.

Pierwsza wojna światowa, podczas której w roku 1915 ewakuowano w głąb Rosji zakłady przemysłowe, uczelnie (również gimnazja) i inne instytucje, pozostawiła swój ślad w życiu kraju. W Rydze jako jedyna szkoła średnia pozostało gimnazjum Emilii Lichtarowiczówny (jeszcze nie miało formalnych praw gimnazjalnych z powodu nieporozumień kierownictwa $\mathrm{z}$ wladzami rosyjskimi). Wobec olbrzymiego napływu do niego dzieci innych narodowości, utraciło ono charakter szkoły polskiej, przechodząc całkowicie na język rosyjski. Z kolei w okupowanej przez Niemców Libawie (Liepaja) w roku 1915 otwarto pierwszą polska szkołę podstawową w tym mieście (dla dziewcząt) ${ }^{2}$. W związku z wielkim napływem uchodźców wojennych z Polski w Rydze i Latgalii utworzono kilka szkół dla ich dzieci ${ }^{3}$, ale nie były one stałe $\mathrm{i}$ po odjeździe uchodźców do Rosji albo ojczyzny w roku 1918 zostały zlikwidowane.

Na początku 1919 roku Armia Czerwona zajęła prawie całe terytorium Lotwy. Chociaż polityczna dzjałalność narodowa była niemożliwa, wladza radziecka pozwalała na organizacje działalności oświatowej mniejszości narodowych. W trzech powiatach Latgalii pracowało 17 szkół polskich, a w Rydze w marcu 1919 roku oprócz 32 szkół łotewskich było 14 szkół rosyjskich, 18 niemieckich, 2 litewskie i 4 polskie (w tych ostatnich - 908 uczniów) 4

Dopiero po stopniowym wyzwoleniu państwa, w niepodległej Republice Lotewskiej działalność mniejszości polskiej osiągnęła najwyższy szczyt $w$ historii ${ }^{5}$. Jednym $z$ elementów

\footnotetext{
1 Państwowe Archiwum Historyczne Lotwy (dalej PAHL), 1536 f., 1 op., 234 t., s. 379, 5213 f., 1 op., 4753 t.

2 "Dzwon" 1929, 1 stycz.

3 Dzimtenes Vestnesis, 1915. 13. janv. 8. 480 .

J. Kronlins, Latvijas skolas lienieku laikả, Izglïtibas Ministrijas Mênešraksts (dalej IMM) - 1929, nr 12,

'Szególnie w: J. Albin, Polski ruch narodowy na Lotwie w latach 1919-1940, Wrocław, 1993; E. Jekabsons Poll Latvija. Riga, 1996.
} 
Tabela 1. Liczba szkół polskich na Lotwie w okresie parlamentaryzmu (1919-1934)

\begin{tabular}{|c|c|c|c|c|c|c|c|c|c|c|c|c|}
\hline \multirow{2}{*}{$\begin{array}{c}\text { Rok } \\
\text { szkolny }\end{array}$} & \multicolumn{3}{|c|}{ Szkoły podstawowe } & \multicolumn{3}{|c|}{ Szkoty zawodowe } & \multicolumn{3}{|c|}{ Gimnrzja } & \multicolumn{3}{|c|}{ Razem } \\
\hline & Szkoly & $\begin{array}{l}\text { Ucmio- } \\
\text { wie }\end{array}$ & $\begin{array}{c}\text { Nauczy- } \\
\text { ciele }\end{array}$ & szkoly & $\begin{array}{l}\text { Ucznio- } \\
\text { wie }\end{array}$ & $\begin{array}{c}\text { Nauczy- } \\
\text { ciele }\end{array}$ & Szkoły & $\begin{array}{c}\text { Ueznio- } \\
\text { wie }\end{array}$ & $\begin{array}{c}\text { Nauczy- } \\
\text { ciele }\end{array}$ & Szkoly & $\begin{array}{c}\text { Ucznio- } \\
\text { wie }\end{array}$ & $\begin{array}{c}\text { Nauczy- } \\
\text { ciele }\end{array}$ \\
\hline 1 & 2 & 3 & 4 & 5 & 6 & 7 & 8 & 9 & 10 & 11 & 12 & 13 \\
\hline $1919 / 1920$ & 17 & 3600 & 120 & - & - & - & - & - & - & 17 & 3600 & 120 \\
\hline $1920 / 1921$ & 19 & 4523 & 153 & - & - & - & 1 & 35 & 10 & 20 & 4558 & 163 \\
\hline $1921 / 1922$ & 27 & 536 & 169 & - & - & - & 3 & 90 & 26 & 30 & 5456 & 195 \\
\hline $1922 / 1923$ & 34 & 5665 & 204 & - & - & - & 3 & 172 & 49 & 37 & 3837 & 253 \\
\hline $1923 / 1924$ & 29 & 4806 & 202 & - & - & - & 3 & 234 & 44 & 32 & 5040 & 246 \\
\hline $1924 / 1925$ & 26 & 4686 & 205 & - & - & - & 3 & 288 & 48 & 29 & 4974 & 253 \\
\hline $1925 / 1926$ & 22 & 3915 & 191 & - & - & - & 4 & 334 & 59 & 26 & 4249 & 250 \\
\hline $1926 / 1927$ & 27 & 4065 & 207 & - & - & - & 3 & 316 & 41 & 30 & 4381 & 248 \\
\hline $1927 / 1928$ & 31 & 4265 & 223 & 1 & 40 & 5 & 3 & 337 & 42 & 35 & 4642 & 270 \\
\hline $1928 / 1929$ & 34 & 4117 & 217 & 1 & 66 & 8 & 3 & 326 & 43 & 38 & 4509 & 268 \\
\hline $1929 / 1930$ & 36 & 4570 & 212 & 1 & 79 & 10 & 3 & 323 & 44 & 40 & 4972 & 266 \\
\hline $1930 / 1931$ & 45 & 5274 & 240 & 1 & 98 & 11 & 3 & 320 & 45 & 49 & 5692 & 296 \\
\hline $1931 / 1932$ & 36 & 4761 & 214 & 1 & 61 & 11 & 3 & 313 & 44 & 40 & 5135 & 269 \\
\hline $1932 / 1933$ & 34 & 4571 & 200 & 1 & 58 & 9 & 3 & 291 & 45 & 38 & 4920 & 254 \\
\hline $1933 / 1934$ & 35 & 4636 & 210 & 1 & 64 & 10 & 3 & 293 & 43 & 39 & 4993 & 263 \\
\hline
\end{tabular}

podstawowych tej działalności było właśnie szkolnictwo. Zaraz po oswobodzeniu Rygi od bolszewików (w maju 1919 roku) były w niej 3 polskie szkoły podstawowe (przed wojną światową - 7) z 800 uczniami oraz przytułek Polskiego Towarzystwa Dobroczynności. Szybko problem finansowania tych szkół był rozwiązany ich przejęciem przez państwo i nowo powstałe samorzady. W grudniu 1919 roku w Rydze działały 4, a w Liepaje - 3 polskie szkoły. W roku szkolnym 1919/1920 na Lotwie było 17 polskich szkód podstawowych z 3600 uczniami i 120 nauczycielami, w roku następnym - 19 szkół a jeszcze w następnym roku 27 - szkód.

Do 1921 roku polskie szkoły pracowały bez specjalnej instytucji kierowniczej w Ministerstwie Oświaty, chociaż już od połowy roku 1920 istnial zarząd oświaty niemiecki, rosyjski i żydowski (głównie dzięki większej aktywności przedstawicieli tych mniejszości narodowych). 15 lutego 1921 prace w Departamencie Mniejszości Narodowych w ministerstwie rozpoczął również Zarząd Oświaty Polskiej w składzie 5 (później 4) osób. Kierownikiem tego zarządu (który miał formalne prawo uczestniczyć w posiedzeniach rządu państwa związanych $\mathrm{z}$ działalnością mniejszości polskiej) był wysunięty przez polskie organizacje Rygi były nauczyciel gimnazjum w Tomsku Józef Ronczewski, kandydatura którego zadowalała również poselstwo polskie, ale nie zadowalała organizacji polskich Latgalii (uważano go za zbyt ustępliwego w sprawach narodowych i zarzucano mu poddanie sie rusyfikacji). Wywołało to ostre nieporozumienie w ramach samego spoleczeństwa polskiego. Sytuacja szczególnie zaostrzyła się po konflikcie, związanym z działalnością nierejestrowanych polskich szkół podstawowych w powiecie daugavpilskim w roku 1921. W kwietniu tego 
roku został aresztowany inspektor Zarządu Polskiej Oświaty Ministerstwa Oświaty i dyrektor prywatnego polskiego gimnazjum Daugavpils Kazimierz Próchnik oraz jeszcze kilku nauczycieli polskich. Oskarżano ich o organizowanie i kierownictwo sieci nielegalnych szkól w Latgalii południowej. Po długiej dyskusji dyplomatycznej K Próchnik został wydalony z Lotwy w końcu roku 1921. Kwestia kierownictwa Zarządu Oświaty Polskiej została rostrzygnięta dopiero w październiku 1922, kiedy na czele tej instytucji po śmierci J. Ronczewskiego stanął nauczyciel polskiego gimnazjum w Rezekne Anton Tałat-Kiełpsz (1883-1942), który pozostał jej kierownikiem do roku 1934 i całkowicie zadowalał również radykalnie pod względem narodowym nastrojone organizacje polskie Latgalii. Zarząd urządził swoja bibliotekę, regularnie organizował letnie kursy nauczycieli polskich w Rydze, w których odczyty dawali również lektorzy $z$ wyższych uczelni w Polsce, przy zarządzie z prawem doradczym działała rada nauczycieli polskich. W roku 1929 A. Tałat-Kiełpsz został nagrodzony orderem Trzech Gwiazd Lotwy III stopnia'.

Pierwsza polska szkoła średnia - prywatne gimnazjum imienia Emilii i Leona Platerów pod kierownictwem Kazimierza Próchnika (1883 -?) rozpoczęlo pracę w grudniu 1920 roku (z 35 uczniami w 2 klasach) ${ }^{7}$. Po niezatwierdzeniu K. Próchnika na stanowisku dyrektora w roku szkolnym 1920/1921 zostało ono przekształcone w gimnazjum państwowe (dyrektorem był Jan Monczyński, 1886-1978). Podobnie jesienią 1922 roku postąpiono ze stworzonym $w$ końcu 1921 roku prywatnym polskim gimnazjum w Rêzekne. Jego założycielami byli: pierwsza przewodnicząca Związku Polaków Lotwy Stanisława Dowgiałło (? - 1933) A. Tałat-Kiełpsz i jego małżonka Olga Tałat-Kiełpszowna, która od roku 1922 do 1940 pełniła obowiązi dyrektorki tego gimnazjum (będąc Rosjanką dzięki wpływowi męża, przejęła kulturę i język polski). W Rydze jesienią 1921 roku w prywatnym gimnazjum E. Lichtarowiczówny otworzono komplet klas polskich, a jesienią 1925 roku szkołę przekształcono w miejskie gimnazjum polskie, wydzielając środki na urządzenie biblioteki i odpowiednie wyposażenie klas. Dyrektorem gimnazjum zatwierdzono dotychczasowego nauczyciela matematyki Józefa Mierzwińskiego (1885-1949). Wszystkie gimnazja polskie były 4-klasowe (pełne), miały bursy. Absolwenci gimnazjów polskich mieli prawo studiować we wszystkich wyższych uczelniach. Ale z powodu trudnych egzaminów wstępnych dla absolwentów gimnazjów mniejszościowych wielu Polaków z Lotwy studiowało w Polsce (w roku 1929 ze 120 studiujących w Polsce Polaków z Lotwy $37 \%$ kończyło polskie gimnazjum w Daugavpils, $16 \%$ - w Rêzekne, $9 \%$ - w Rydze, a 38\% - inne gimnazjum Lotwy). W roku 1930 w polskim gimnazjum w Rydze było 129, Daugavpils - 118, a w Rēzekne - 75 uczniów. Na ogól liczba szkół mniejszościowych w stosunku do liczby mieszkańców była większa, niż liczba szkół łotewskich. U Polaków ta różnica nie była tak zauważalna, jak na przykład u Żydów i Niemców. Szczególnie dotyczyło to Łatgalii, gdzie w roku 1925 Lotysze mieli jedna szkołe na 51215, Żydzi - 7940, Polacy - na 12782 mieszkańców. Ogólnie na Lotwie sytuacja była następująca: Lotysze mieli szkołę średnią na 26551, Żydzi - 5035, Niemcy - 7096, Polacy - na 17044 mieszkańców ${ }^{8}$. Oczywiście, że pewna ilość dzieci $z$ rodzin polskich uczyła się w szkołach innych narodowości, natomiast w szkołach polskich - dzieci niepolskie. Szczególnie wyraźnie to było widać w Latgalii, gdzie, w wyniku szczególnej drogi rozwoju historycznego tego obszaru, świadomość narodowa wielu miejscowych Lotyszów byla rozwinięta jeszcze stosunkowo słabo. Udowadniają to liczne łotewskie nazwiska w spisach absolwentów polskich szkól jeszcze w okresie międzywojennym, jak również wiele innych świadectw. Przykladowo konsul Polski w Daugavpils (były ziemianin Latgalii) M. Świerzbiński w roku 1922 meldował, że wielu Lotyszów chętnie oddaje swoje dzieci do polskich szkót?

" IMM. - 1928. - Nr. 11. - 8. 388; PAHL, 2574 f, 3 op., 92 t.; „Tygodnik Polski” 1925, 26 luty; „Dzwon” 1929, 24 list.

'J. Kronlins, Latvijas vidusskolas, IMM - 1922 nr 4, 8. 359.

PAHL, 2574 f., 3 op., 91 t., 574 s; „Dzwon”, 1929, 1 stycz; IMM, 1927, nr 3, s. 25.

9 Archiwum Akt Nowych, Kolekcja odpisów dokumentów, t. 4, s. 294. 
Od 1928 roku w Daugavpils pracowała polska szkoła rzemieślnicza, do której przyjmowano absolwentów 4 albo 6-klasowych szkół podstawowych. W szkole były oddziały mechaniki i sztuki kowalskiej, stolarstwa oraz szycia. Przez pewien czas istniał także oddział murowania pieców. Pierwsi absolwenci ukończyli szkołę w roku 1931, a w sierpniu 1934 w celach oszczędności została ona zamknięta, dając możliwość uczniom kontynuowania nauki w Państwowej Szkole Rzemieślniczej w Daugavpils. W roku 1929 Związek Polaków Lotwy i dwaj jego przedstawiciele w Sejmie uzyskali zgodę Komisji Budżetowej na przekazanie sumy 9000 latów na stworzenie polskiej szkoły rolniczej w Laucese, ale ostatecznie projekt nie zostal zrealizowany z powodu sprzeciwu socjaldemokratów w Sejmie $^{10}$.

Z kolei liczba podstawowych szkół polskich do roku 1923 ciagle rosła. Pracowały one według ustawy o szkolnictwie z grudnia 1919 roku, która przewidywała, że każda mniejszość narodowa na Lotwie ma prawo do pewnej liczby szkół (odpowiadającej ilości ogółu mieszkańców konkretnej narodowości). Można było utworzyć szkołę, jeśli liczba dzieci wynosiła conajmniej 30. W związku z tym, że w niektórych miejscowościach Latgalii mieszkaricy nie mieli przekonania o własnej narodowości, stale się zmieniała również liczba szkól. Natomiast w miastach była ona mniej więcej stała. Większa część polskich szkół podstawowych była finansowana przez samorządy miejskie i gminne. W Rydze liczba polskich szkół podstawowych stopniowo wzrosła z $4 \mathrm{w}$ roku 1920 do $6 \mathrm{w}$ roku szkolnym 1933/1934. Oprócz tego pracowała tutaj od roku 1931 w pomieszczeniach polskiego gimnazjum także polska szkoła wieczorowa i polska szkoła uzupełniająca (obydwie w ramach budżetu miejskiego). W szkole uzupełniającej absolwenci szkół podstawowych mogli uczyć się księgowości, maszynopisania, stenografii itd. Istnial także komplet klas polskich w 43 szkole podstawowej oraz polskie przedszkole. W Liepāje z 3 polskich szkół podstawowych jedną zamknięto na początku lat 20-tych, a dwie pozostałe w roku 1929 połączono w jedną. W Daugavpils w roku 1920 pod opieką samorządu znajdowały się 4 polskie szkoły podstawowe oraz 2 polskie przedszkola Liczba szkół podstawowych $w$ tym mieście pozostawała niezmienna do roku 1934, kiedy uczyło się w nich 1374 uczniów. Od roku 1920 polska szkoła była w Rẽzekne (w 1934 - 244 uczniów). Jeszcze w chwili przewrotu państwowego w roku 1934 pracowała polska szkoła podstawowa w Jelgawie (Mitawie) z 60 uczniami, 2 szkoły w Griva (Grzywa) z 128 uczniami, szkoła w Krâ̄slava (Kraslaw) z 215, w gminie Naujenes (88), po 2 w gminie Skaistas (174) i Kapinu (144), szkoła w gminie Jasmuižas (33), w Kombulach (38), Pusze (47), Kaunacie (36), Malta (65), Rêzna (39), Feimani (48), Pasiene (198) i Rundêni (54). W omawianym okresie $w$ Latgalii i powiecie Ilūkste (Iluksztańskim) byłej gubernii Kurlandskiej zamknięto kilka szkół polskich. Znaczniejsza wśród nich była polska szkoła podstawowa w Ludza (Lucynie), która skończyła swoją działalność w roku 1932 (w istniejącej od jesieni 1920 roku było wtedy aż 150 uczniów) $)^{11}$.

Po dokonanym 15 maja 1934 roku przez premiera $K$. Ulmanisa przewrocie państwowym sytuacja wewnętrzna w kraju znacznie się zmieniła. Zawieszono działalność Sejmu oraz organizacji politycznych, rozpoczęto aktywną łotyszyzację wszystkich sfer życia państwa. Przemiany godziły również w system szkolnictwa mniejszości narodowych. Już latem 1934 zlikwidowano mniejszościowe zarządy oświaty w Ministerstwie Oświaty, zamieniając ich jedynie stanowiskami referentów do spraw mniejszościowych. Referentem do spraw oświaty polskiej mianowano nauczyciela oraz aktywnego uczestnika ruchu harcerstwa polskiego (w ramach organizacji skautingu łotewskiego) z Liepaji Romana Ciesiulewicza (1905-?), jednym z głównych jego zadań było organizacja tłumaczenia podręczników szkół polskich, a także pisania zupełnie oryginalnych podręczników dla tych szkół ( $\mathrm{z}$ kolei wydane w Polsce podręczniki miały być przed użyciem w szkołach Lotwy zatwierdzone w Ministerstwie Oświaty). Ogólnie od roku 1933 państwo łotewskie wydało 14

\footnotetext{
${ }^{10}$ IMM 1934, nr 10, s. 433; E. Jekabson, Jeszcze o szkolach polskich, „Polak na Lotwie" 1992, nr 2; „Dzwon” 1929, 14 marzec, 6 kwiec.

il PAHL, 2574 f, 3 op., 2733 t., 104 s.; 90 t, 313 s; 3723 f., 2 op., 146 t., 273 - 279 s.; Archiwum Akt Nowych, Ministerstwo Spraw Zagranicznych, 10475 t, s. 118 - 119.
} 
podręczników dla szkół polskich (w tej liczbie również „czytanki” języka polskiego autorstwa Polek łotewskich L. Mundeciemówny i W. Ootówny). Oprócz tego w roku 1931 w Daugavpils i w roku 1937 w Rydze wydano podręcznik matematyki nauczyciela M. Makowskiego. W związku z likwidacją kursów letnich polskich nauczycieli gwarantowano im miejsca $w$ instytutach nauczycielskich w Rēzekne i Rydze. Jak wspomniano wyżej, zamknięto polską szkołę rzemieślniczq w Daugavpils. Natomiast w roku 1935 w tym mieście połączono gimnazja polskie, rosyjskie i białoruskie, tworząc 2 mieszane gimnazjum miejskie i nie przyjmując do niego nowych uczniów (część uzyskanych takim sposobem środków kierowano na utrzymanie innych szkół polskich). Z kolei polskie miejskie gimnazjum w Rydze w roku 1935 przeksztalcono w gimnazjum państwowe z poetą lotewskim Antonem Bārda (1891-1981) jako dyrektorem (od 1925 roku pracowal w gimnazjum jako nauczyciel języka lotewskiego). Zmniejszyła się również liczba polskich szkół podstawowych, co było wywołane w dużej mierze nową ustawą oświatowa, która dawała prawo do stworzenia szkoły w wypadku, jeśli liczba dzieci osiągała 80 (wcześniej $-30)^{12}$.

W czerwcu 1940 roku 2 państwowe gimnazjum Daugavpils ukończyla ostatnia polska klasa. Szkól podstawowych w roku szkolnym 1939/1940 nadal było 16 (4 szkoły podstawowe, szkoła wieczorowa w Rydze z 893 uczniami, szkoła w Liepãja ze 133, komplet klas polskich w 3 szkole podstawowej w Jelgava z 33, szkoła w Daugavpils z 373, Krâslava z 61, Rêzekne z 192, komplet klas w szkole podstawowej Puszi z 22 , szkoła w Malta z 45, Pasiena z 95, komplet klas w Feimani z 36 uczniami). Jak widać, liczba polskich szkó podstawowych w ciągu 6 lat znacznie zmalała. Przewidziana w nowej ustawie oświatowej liczba uczniów (dla otworzenia szkoły - 80, klasy - 30) często byla powodem zamknięcia szkół i klas polskich. $Z$ kolei aktualna (niedostateczna) liczba uczniów w kilku wypadkach wynikała również z działalności komisji Ministerstwa Oświaty, które częstokroć usuwało ze szkól polskich dzieci, których narodowe pochodzenie mogło budzić wątpliwości (na przyklad, jeśli mieli łotewskie nazwiska). Już w roku 1934 zlikwidowano obydwie polskie szkoły podstawowe w Griva (w jednej było 78, w drugiej - 50 uczniów) i kilka szkół w Latgalii, a 4 szkoły w Daugavpils połączono, tworząc 2 (w roku 1937 obydwie połączono w jedną), w roku 1936 zamknięto 3 ryską polską szkołę podstawową (68 uczniów), w 1937 roku - szkołę w Jelgawa (48), tworząc zamiast niej komplet klas polskich w 3 szkole podstawowej. Szczególnie nienaturalna sytuacja istniała w Latgalii, gdzie w kilku wypadkach liczba uczniów szkół polskich naprawdę była bardzo niska (na przykład w komplecie polskim szkoły Krasta w gminie Skaistas w roku szkolnym 1935/36 był tylko jeden uczeń). Jednocześnie dyrektor Departamentu Szkolnego K. Ozolins w roku 1939 meldował, że stosunek do szkół polskich jest znacznie lepszy niż do rosyjskich i niemieckich, o czym świadczy również sytuacja w niektórych szkołach w Rydze, Krāslawie i innych miejscach, gdzie liczba uczniów byla znacznie niższa od przewidzianej (należy przyznać, że taki stan rzeczy byl powodowany głównie działalnością poselstwa polskiego i stosunkowo dobrymi stosunkami międzypaństwowymi lotewsko-polskimi). Również wydatki na jednego ucznia w polskich szkołach wynosity 131, a w lotewskich - tylko 72 lata (w gimnazjach odpowiednio 390 i 165). Z drugiej strony nie można nie zauważyć, że jedynie z powodów politycznych (terytorialne pretensje Polski do Lotwy w niedalekiej przeszlości) zamknięto zupełnie wszystkie szkoły polskie w powiecie Ilūkste oraz nie pozwolono na otwarcie nowych. Ale w sumie należy wnioskować, że Polacy i inne mniejszości narodowe nadal mogli rozwijać swoją kulturę i uczyć się w szkołach ze swoim językiem wykładowym. W roku szkolnym 1937/38 na Lotwie była jedna szkoła średnia na 8498 Żydów, 8878 Niemców, 22913 Litwinów, 24474 Polaków i 27785 Lotyszów ${ }^{13}$.

12 "Nasze Życie" 1935, 2 czerw, 1 wrz., 18 sierp.

13 PAHL, 2574 f., 3 op., 2733 t.; K. Ozolinł̌, Izglitibas ministrija savas darbibas abos primajos gadu desmitos, IMM - 1938, nr 11, \&. 490. 
Tabela 2. Liczba polskich szkól na Latwie w okresie ustroju autorytarnego (1934-1939)

\begin{tabular}{|c|c|c|c|c|c|c|c|c|c|}
\hline \multirow{2}{*}{$\begin{array}{c}\text { Rak } \\
\text { szkolny }\end{array}$} & \multicolumn{3}{|c|}{ Szkoly pods Lawowe } & \multicolumn{3}{|c|}{ Gimnazja } & \multicolumn{3}{c|}{ Razem } \\
\cline { 2 - 10 } & Szkody & $\begin{array}{c}\text { Ucznio- } \\
\text { wie }\end{array}$ & $\begin{array}{c}\text { Nauczy- } \\
\text { cizle }\end{array}$ & Szkoly & $\begin{array}{c}\text { Ucznio- } \\
\text { wie }\end{array}$ & $\begin{array}{c}\text { Nauczy- } \\
\text { ciele }\end{array}$ & Szkoły & $\begin{array}{c}\text { Uanio- } \\
\text { wie }\end{array}$ & $\begin{array}{c}\text { Nauzy- } \\
\text { ciele }\end{array}$ \\
\hline $1934 / 1935$ & 22 & 2903 & 150 & 3 & 268 & 41 & 25 & 3171 & 191 \\
\hline $1935 / 1936$ & 21 & 2423 & 132 & 2 & 178 & 29 & 23 & 2601 & 161 \\
\hline $1936 / 1937$ & 18 & 2279 & 125 & 2 & 178 & 33 & 20 & 2457 & 158 \\
\hline $1937 / 1938$ & 16 & 2129 & 119 & 2 & $179(97)$ & 35 & 18 & 2308 & 154 \\
\hline $1938 / 1939$ & 16 & 1933 & 112 & 2 & $186(30)$ & 35 & 18 & 2149 & 147 \\
\hline
\end{tabular}

- W nawiasach podano liczbe uczniów ka polskich w 2 państwowym gimnazjum Daugavpils

Życie społeczne Polaków na Lotwie zostało prawie całkowicie zlikwidowane natychmiast po okupacji państwa przez Armię Czerwoną latem 1940 roku. Ale jeszcze w roku szkolnym 1940/1941 pracę kontynuowało 11 polskich szkół podstawowych oraz 2 gimnazja. Liczba szkół podstawowych zmalała dlatego, że w sierpniu 1940 roku połączono 1 szkołe podstawową (większą) z gimnazjum ryskim, tworząc 15 miejską szkołę z polskim językiem nauczania i D. Lukasiewiczem jako dyrektorem. W roku 1941 ostatnia klasę tej szkoły skończyło 14 uczniów ${ }^{14}$. W szkołach polskich bylo widoczne rozpoczęcie procesu rusyfikacji uczniów.

Wśród dziesiątków tysięcy represjonowanych przez władze radziecka obywateli Łotwy było również wielu Polaków. Zostali aresztowani i wywiezieni do więzień albo obozów koncentracyjnych (również ośmiu polskich pedagogów, m.in. były kierownik Zarządu Oświaty Polskiej A. Tałat-Kiełpsz, dyrektorka gimnazjum w Rēzekne $O$. Tałat-Kiełpszowna, nauczyciele z Daugavpils Wacław i Bolesław Baużykowie $i$ inni $)^{15}$. Prawie wszyscy aresztowani mężczyźni albo otrzymali wyroki śmierci radzieckich „sqđów”, albo zginęli w obozach zagłady.

W roku 1941 okupację radziecką (albo rosyjska, jak ją powszechnie rozumiano) zmieniła okupacja niemiecka, która dla Polaków była również ciężka. Tylko w roku szkolnym 1943/1944 przez niedługi okres czasu pracowała w Rydze polska szkoła, która skończyła działalność po aresztowaniu $\mathrm{i}$ wysłaniu do obozu $\mathrm{w}$ Stutthofie jednego $\mathrm{z}$ dwóch nauczycieli - J. Krasowskiego ${ }^{16}$.

Po zajẹciu terytorium Lotwy w roku 1944 - 1945 władza radziecka dopuściła działalność kilku szkól polskich, ale jednocześnie były one celowo poddane radzieckim metodom pedagogiki i rusyfikacji. W roku 1949 zamknięto ostatnią polską szkołę. Oświata polska na Lotwie przestała istnieć do 1989 roku, kiedy podczas procesu odbudowy państwowości łotewskiej w Rydze i Daugavpils, a później również w innych miejscach odrodziły się szkoły polskie. s. 26.

${ }^{14}$ Z. Ihnatowice, Przyczynek do dziejów oświaty polskiej na ziemi lotewskiej, „Polak na Lotwie” 1991, nr 2,

is J. Kronlins, 379 dienas můsu jaunatnes un skolu liktenos bolševiku varas gadā, Rīga, 1944; These Names Accuse, Stockholm 1982.

16 Z. Ihnatowicz, Przyczynek.., s. 26. 